\title{
Production Practices for Satsuma Mandarins in the Southeastern United States
}

\author{
Monte L. Nesbitt ${ }^{1,4}$ \\ Department of Horticulture, Auburn University, Gulf Coast Research \& Extension Center, \\ 8300 State Highway 104, Fairhope, AL 36532 \\ Robert C. Ebel ${ }^{2}$ and William A. Dozier, Jr. ${ }^{3}$ \\ Department of Horticulture, Auburn University, 101 Funchess Hall, Auburn, AL 36849 \\ Additional index words. microsprinkler irrigation, high tunnel houses, nitrogen fertilization, pruning
}

\begin{abstract}
Satsuma mandarin is presently the primary citrus crop for citrus growers in south Alabama, south Mississippi, and for certain new plantings in northwest Florida. Current growth in satsuma mandarin hectarage in Alabama is similar to the historical hectarage expansion that occurred during decades or clusters of years with a low incidence of lethal, freezing temperatures. Commercial groves currently range in size from 100 to 2000 trees and use various freeze protection strategies, including wind breaks, overstory frost protection with pine or pecan trees, under-tree and scaffold branch irrigation, and high tunnel polyethylene-covered greenhouses. The various methods of freeze protection require adjustments in cultural management practices, including spacing, pruning, irrigation, and fertilization. The primary rootstock used and recommended for its cold-hardiness and edaphic adaptation is Poncirus trifoliata. Some groves use 'Swingle' citrumelo, mainly because it is grown and propagated in Louisiana, where it is valued for its higher salt tolerance. 'Owari' was the original cultivar introduced to the United States from Japan in the late 19th century and is still the main cultivar in Alabama today, although earlier maturing cultivars, including 'Brown Select', 'Early St. Ann', and 'LA Early', are being introduced to extend the marketing season. Cultivars from Japan and China, including 'Okitsu Wase', 'Miyagawa Wase', and 'Xie Shan', are currently being evaluated for suitability in the region. Three general methods of culture with regard to spacing and pruning are discussed. Nitrogen application rates are typically low to moderate, yet leaf nitrogen levels surveyed in groves in $\mathbf{2 0 0 5}$ were generally optimal or high with respect to published sufficiency levels for mature citrus in Florida.
\end{abstract}

Satsuma mandarin (Citrus unshiu Marc.) has been grown in southern Alabama, southern Mississippi, and northwestern Florida with intermittent commercial success since its introduction from Japan in the late 1800s. Occasional winter freezes and the absence of an economical and fail-safe means of freeze protection relegated the plant to dooryard and small-scale commercial production throughout most of the 20th century. Bourgeois et al. (1990) demonstrated tree survival of satsumas during the 1989 freeze in Louisiana at a low of $-11{ }^{\circ} \mathrm{C}$ with scaffold branch irrigation and Nesbitt et al. (2000) demonstrated survival and rapid return to production of trees exposed to $-9.4{ }^{\circ} \mathrm{C}$ in Alabama. Although neither of these studies provided certainty that satsumas could be kept alive and productive against the historical low temperatures of the region, they demonstrated a cost-effective and labor-saving means of mitigating freeze injury to temperatures as low as $-11{ }^{\circ} \mathrm{C}$, which can result in mild, cropreducing injury or complete death. The acceptance of this technology by growers, coupled with an absence of significantly injurious freezes on the Gulf Coast since 1996, has generated interest in satsuma mandarin production across multiple counties in Alabama and in the panhandle region of Florida.

\footnotetext{
${ }^{1}$ Agricultural Program Associate II.

${ }^{2}$ Associate Professor.

${ }^{3}$ Professor.

${ }^{4}$ To whom reprint requests should be addressed; e-mailnesbiml@auburn.edu
}

An informal grower questionnaire/survey conducted in Nov. 2005 revealed that Alabama had $\approx 7000$ trees in the Baldwin/Mobile County area in 13 groves, representing $\approx 25.3$ ha. Respondents also indicated that another 10.1 ha were planned for planting in 2006 . Grove size among this group of growers ranged from 100 to 2000 trees, and eight of 13 groves had fewer than 300 trees. Alabama also has 500 trees in three groves in Escambia County; 300 trees in three groves in Houston County, near the city of Dothan; and 175 trees in three groves north of Montgomery. The trees near Montgomery are grown in "high tunnel" greenhouse production. The 2005 survey also tabulated 400 trees in one grove near Gulfport, MS, and 1610 trees in three groves near Marianna, FL. Trees ranged in age from 1 to 22 years old in the groves in Baldwin and Mobile Counties, where small numbers of trees survived the winter 1983 to 1984 freeze, but most were planted after the winter 1989 to 1990 freeze. All of the plantings described in the survey that were in Florida, Mississippi, or other counties of Alabama were 6 years old or less. Although the reported total of $\approx 10,000$ trees collectively represents a very small citrus industry, it does signify grower enthusiasm, potential for further increases in hectarage, and the need for refinement of cultural methods.

Three different methods of satsuma mandarin culture are used in the Gulf Coast region with the difference resulting from freeze protection method. The foremost method is the "irrigated grove" with irrigation designed and installed principally for grove freeze protection. Trees in this method are usually planted $4.6 \mathrm{~m}$ to $6 \mathrm{~m}$ within rows and $6 \mathrm{~m}$ to $7.6 \mathrm{~m}$ between rows giving a tree density of 269 to 287 trees per hectare. Little pruning is done with this method other than "skirting" (removal of low limbs to facilitate herbicide application) and heading back of the uppermost portion of the canopy every third or fourth year to limit overall height and facilitate hand-harvest of all of the fruit from the ground.

Wind break plantings have not been used in most of these irrigated groves, although they are recommended, and some growers use natural wind breaks such as forested areas to reduce north wind velocity during advective freezes. At the time of planting, a single microsprinkler is situated on the ground in the northwest quadrant of each tree to spray directly on the graft union and lowest branches. The water volume recommended per tree at planting is $45 \mathrm{~L} \cdot \mathrm{hr}$, which is adequate for freeze protection for the first 4 years of growth and production. After the fourth growing season, a second sprinkler is added for each tree and placed within the established canopy having a volume equal to or greater than the first. Alternatively, the original sprinkler may be placed within the canopy and the water volume increased to 90 $\mathrm{L} \cdot \mathrm{hr}$ by replacing the emitter (Nesbitt et al., 2000).

The second method of culture is the "interplanted grove," in which satsuma mandarin trees are interplanted with pine trees, either Loblolly Pine (Pinus taeda) or Slash Pine (Pinus elliottii), to reduce frost injury during the winter season or pecan trees in a double culture system. Pine trees were used by growers in the region before the advent of irrigation technology and are still used today 
on a limited scale. The southeastern United States commonly experiences both advective and radiational freezes in winter with the former having the greatest potential for causing tree death and the latter causing less serious but chronic foliage and crop damage. The overstory of mature pine trees provides significant protection from radiational frost injury but little freeze protection during severe advective freezes. The interplanted groves in Alabama or Mississippi that are currently in production and appear to be successful to date have not experienced a severe advective freeze; thus, this cultural method may not be used long term.

Tree spacing in interplanted groves is typically closer than in irrigated groves with in-row spacing of $3 \mathrm{~m}$ to $4.3 \mathrm{~m}$ and betweenrow spacing of $6 \mathrm{~m}$ giving a tree density of 359 to 384 trees/ha. Every third tree in each row of trees is a pine tree and alternating rows have pines in alternating positions. When planted at the same time, the pine trees offer little frost protection to the satsumas during the first 4 to 6 years of growth and development and then provide increased frost protection with each year of canopy growth of the overstory species. Shading from the pine trees appears to reduce yield of satsuma mandarins, although annual production has not been formally measured. Fifteen-yearold loblolly pines cause an $80 \%$ reduction in photosynthetically active photon flux density at midday in interplanted groves compared with irrigated groves of similar age (unpublished data). The reduced light levels cause trees to be more sparsely foliated with long branches and large leaves; thus, more pruning has been required compared with irrigated groves. Satsuma mandarin fruit develops and ripens more slowly in interplanted groves (unpublished data), but final quality is similar to trees in full sun, and fruit have fewer blemishes from reduced wind velocity.

The third method of culture is "high tunnel greenhouse" production with trees permanently planted in greenhouses that are covered in the months of December to April with a single layer of white, 4-mil or 6-mil polyethylene plastic. The structures themselves vary in width, length, and height, and planting arrangement varies from double-row with a spacing of $1.8 \mathrm{~m}$ in-row and $3.6 \mathrm{~m}$ between rows to single-row with trees spaced $1.8 \mathrm{~m}$ to $2.4 \mathrm{~m}$ apart. Supplemental heat is provided by typical greenhouse heaters and water is stored in black-colored drums or with microsprinklers. Trees grown at present in high tunnels are less than 6 years old and pruning requirements, potential for overcrowding, and yield potential are currently under study.

The main rootstock for all methods of growing satsuma mandarins in Alabama, west Florida, and south Mississippi is Poncirus trifoliata (L.) Raf., commonly known as Trifoliate Orange. P. trifoliata has excellent cold-hardiness (Yelenosky et al., 1973), and satsuma mandarin grafted on it is one of the most cold-hardy citrus plants with commercial market potential (Yelenosky, 1985).
Poncirus trifoliata is a good rootstock for the acidic and clayey soils of the region (Davies and Albrigo, 1994), is resistant to Citrus Tristeza Virus (CTA), which has been detected in Louisiana and Alabama (Valverde et al., 2004), and growers have not reported problems with nematodes. Citrus blight and citrus canker could be future problems for growers in the Southeast because $P$. trifoliata is susceptible to both. The most common cultivar of $P$. trifoliata grown in the region is 'Rubidoux', although many trees are produced from seedling trees of unknown origin. Satsuma mandarin on $P$. trifoliata attains a height of $3.7 \mathrm{~m}$ in $\approx 10$ years, and little pruning is done other than "skirting" or removal of lower limbs that hang to the ground. Some satsumas are currently being planted on the 'Flying Dragon' cultivar of $P$. trifoliata to produce smaller trees, particularly for high tunnel culture.

'Swingle' citrumelo (Citrus paradisi Macf. 'Duncan' $\times P$. trifoliata) became a primary rootstock for satsuma growers in Plaquemines Parish, LA, in the 1990s as a result of poor performance of $P$. trifoliata on soils experiencing increased salinity. 'Swingle' has a combination of desirable traits, including soil type adaptability, disease resistance, and cold tolerance (Hutchison, 1974), making it a reasonable, alternative rootstock to P. trifoliata for Alabama citrus. Because citrus nurseries in Plaquemines Parish supply citrus trees to Alabama, Mississippi, and even Georgia, the number of citrus trees in this region on 'Swingle' has increased significantly over the past decade.

The original satsuma mandarin cultivar that was introduced to the United States from Japan in the late 1800s is 'Owari', a cultivar that reaches desirable eating quality in early November in south Alabama (Ebel et al., 2004). 'Owari' is still the predominant cultivar of satsuma mandarin in the region today, accounting for $80 \%$ to $90 \%$ of the grove cultivar composition. 'Armstrong Early' is a cultivar of unknown origin that ripens 30 to $40 \mathrm{~d}$ earlier than 'Owari' and has a thin peel and compact growth habit. 'Armstrong Early' has been grown for over two decades, but on a limited scale as a result of inconsistent internal fruit quality. Three cultivars developed in Louisiana are currently of commercial interest in Alabama because they ripen earlier than 'Owari'. The Louisiana releases include the midseason selection 'Brown's Select' (Bourgeois et al., 1995), which ripens 7 to $20 \mathrm{~d}$ earlier than 'Owari' in Alabama, and 'Early St. Ann' (Bourgeois et al., 2002a) and 'L.A. Early' (Bourgeois et al., 2002b), that ripen 30 to $40 \mathrm{~d}$ before 'Owari'. Early-ripening cultivars from Japan and China, including 'Miyagawa Wase', 'Okitsu Wase', and 'Xie Shan', have also been recently introduced to Alabama in experimental trials, and it is unknown at present whether they will consistently bear fruit with acceptable internal quality.

Very few other citrus cultivars are grown in Alabama. Although 'Washington' navel oranges are produced commercially in south Louisiana, no navel or sweet oranges are grown commercially in Alabama. A wide array of citrus may be found in home landscapes in this region, but the only cultivars planted in sufficient numbers for commercial potential include 'Meyer' lemon, 'Meiwa' sweet kumquat (Fortunella crassifolia), and 'Nagami' sour kumquat (Fortunella margarita).

Fertilizer rates currently recommended for satsuma mandarin in Alabama are adapted from grower experience and extension guides for citrus production in other states. Satsuma mandarins in Alabama are grown entirely for fresh consumption, and thin peel, among other traits, is highly desirable. Nitrogen fertilization and peel thickness in citrus are generally believed to be positively correlated (Zekri et al., 2003), and growers in Alabama tend toward low to moderate nitrogen fertilization rates. Under current recommendations in Alabama, annual nitrogen fertilization rate increases annually from $0.09 \mathrm{~kg} /$ tree to $0.68 \mathrm{~kg} /$ tree for 9 -year-old or older trees, which translates to a maximum rate of $\approx 200 \mathrm{~kg} \cdot \mathrm{ha}^{-1}$ depending on planting density. This rate is slightly lower than the maximum recommended for mature citrus in Florida of $224 \mathrm{~kg} \cdot \mathrm{ha}^{-1}$ (Scholberg et al., 2000). Leaf nitrogen levels from six groves in Alabama sampled in Aug. 2005 ranged from $2.61 \%$ to $2.86 \%$, and three of six were above the range for optimal leaf nitrogen for bearing citrus in Florida, which is $2.5 \%$ to $2.7 \%$ (Scholberg et al., 2000). Fertility studies are presently being conducted in Alabama in an effort to determine optimal leaf nitrogen levels and refine rates and application timing for maximizing yield and fruit quality.

The interest in Alabama for profitable agricultural crops that require limited land area is strong, especially in southern Alabama where population growth is rapid and large-hectarage farming is on the decline. Culture for satsuma mandarin production in Alabama is evolving. The continued adoption and implementation of the three methods of culture described here depend on their success in mitigating freeze injury. The interplanted grove as a method of culture will likely be discarded by growers if an advective freeze event occurs with low temperatures of $-9.4{ }^{\circ} \mathrm{C}$ or lower. If irrigated groves and high tunnel plantings continue to protect trees from freeze events at or below $-9.4{ }^{\circ} \mathrm{C}$, then it is likely that satsuma mandarin production will be viewed as a viable specialty crop in this region and hectarage will increase.

\section{Literature Cited}

Bourgeois, W.J., A.J. Adams, and D.R. Stipe. 1990. Effectiveness of scaffold branch irrigation for freeze protection of Louisiana citrus during 1989 freeze. Proc. Fla. State Hort. Soc. 103: 62-64.

Bourgeois, W.J., R.J. Constantin, and A.J. Adams. 1995. 'Brown's Select': A new midseason satsuma cultivar. HortScience 30:391-392. 
Bourgeois, W.J., R.J. Constantin, and M.J. Falcon. 2002a. 'Early St. Ann': A new early maturing datsuma mandarin. La. State Univ. Agr. Ctr. Circular 141.

Bourgeois, W.J., R.J. Constantin, and M.J. Falcon. 2002b. 'LA Early': A new early market satsuma. La. State Univ. Agr. Ctr. Circular 140.

Davies, F.S. and L.G. Albrigo. 1994. Citrus: Crop production science in horticulture. Vol. 2. CAB International, Wallingford, UK.

Ebel, R.C., W.A. Dozier, B. Hockema, F.M Woods, R. Thomas, B.S. Wilkins, M. Nesbitt, and R. McDaniel. 2004. Fruit quality of dat- suma mandarin grown on the northern coast of the Gulf of Mexico. HortScience 39:979-982.

Hutchison, D.J. 1974. Swingle Citrumelo-A promising rootstock hybrid. Proc. Fla. State Hort. Soc. 87:89-91.

Nesbitt, M.L., N.R. McDaniel, R.C. Ebel, W.A. Dozier, and D.G. Himelrick. 2000. Performance of satsuma mandarin protected from freezing temperatures by microsprinkler irrigation. HortScience 35:856-859.

Scholberg, J.M.S., L.R. Parsons, and T.A. Wheaton. 2000. Some production considerations for more efficient nitrogen use. Citrus Industry 81:18-19.
Valverde, R., A. Landry, P. Lotrakul, M. Nesbitt, W. Dozier, and R. Ebel. 2004. Identification of citrus tristeza virus strains in Louisiana and Alabama. Acta Hort. 657:567-571.

Yelenosky, G. 1985. Cold hardiness in citrus. Hort. Rev. (Amer. Soc. Hort. Sci.) 7:201238.

Yelenosky, G., R.T. Brown, and C.J. Hearn. 1973. Tolerance of trifoliate orange selections and hybrids to freezes and flooding. Proc. Fla. State Hort. Soc. 86:99-104.

Zekri, M., T.A. Obreza, and R. Koo. 2003. Irrigation, nutrition and citrus fruit quality. Fla. Coop. Ext. Serv. Doc. SL 207. 